\title{
Self-Regulated Strategic Writing for Academic Studies in an English- Medium-Instruction Context
}

This study explored the processes of utilization of resources in secondary students' selfregulated strategic writing for academic studies in an English as Medium of Instruction context in Hong Kong. Drawing on multiple data sources collected through observation of lessons, stimulated recall and semi-structured interviews, the study examined the features of six secondary students' self-regulated writing with focus on how they used resources strategically to overcome challenges in academic writing. In the analysis, we compared self-regulated strategic writing processes of high achievers and underachievers. Differences were found in the ways resource utilization unfolded in the learners' self-regulated writing activities. Seven processes, namely, noticing, selecting, reorganizing, evaluating understanding, reviewing and memorizing, imitating, as well as adapting, were found in high achievers' self-regulated writing, while only imitating and reorganizing were identified in the case of underachievers. Differences were also found in terms of why and how the high achievers and the underachievers imitated and reorganized resources. The study suggests that underachievers should be encouraged to reflect on their self-regulated writing processes and language teachers can help these students to deploy strategies in ways high achievers use them. We draw on sociocultural theory in our discussion.

Keywords: self-regulated strategic writing, academic studies, English-medium instruction, sociocultural theory, resource utilization

\section{Introduction}

Students face a variety of challenges when learning academic subjects with a second language as the medium of instruction, among which writing unfamiliar genres such as assignments, essays and reports is one of the most notable difficulties (Campbell and Li 2007; Kanno and Harklau 2012). To address such challenges, students may need to develop relevant strategies to facilitate and sustain self-regulated writing (e.g., Oxford 2011). Consequently, it has become important for researchers and practitioners to understand how students self-regulate their writing strategically. 
In the last four decades, researchers have undertaken strenuous efforts to identify learners’ writing strategy usage, though the results have been inconclusive (e.g., Bai 2015; Wong 2005). Research has revealed the differences between strategies used by proficient and less proficient learners in terms of magnitude and/or frequency (e.g., Ghavamnia, Ketabi, and Tavakoli 2013; Griffiths 2013). However, they also found that underperforming language learners too can be active strategy users (e.g., Vann and Abraham 1990). It seems that 'there are no good or bad strategies but it is how the strategies are executed that counts' (Lei 2016, 106). This draws further attention to self-regulated strategic writing processes as carefully coordinated use of a series of strategies that can contribute significantly to learners' success (e.g., Griffiths 2015). For this reason, this study explores self-regulated strategic writing processes that secondary students deploy when overcoming challenges of completing written assignments (e.g., answering questions, completing assignments) for subjects they learn through a second language (i.e. English) as medium of instruction (EMI) in Hong Kong.

\section{Towards self-regulated strategic writing}

Self-regulated strategic writing refers to the dynamic process of using meta-strategies (e.g., paying attention, planning, obtaining and using resources, organizing, implementing plans, orchestrating strategy use, monitoring and evaluating) (Oxford 2011) to guide the use of cognitive strategies, affective strategies and sociocultural-interactive strategies in the writing process. Among these strategies, some comprise of observable actions, such as obtaining and using resources (e.g., 'looking for a suitable dictionary for technical terms that are useful for the writing' and 'organizing the notebook with colours for the tabs') and implementing plans (e.g., 'putting the plan of writing into action'). Others comprise of mental processes that cannot be easily observed, such as evaluating (e.g., thinking about the learning strategies to identify those 
that have worked or are likely to work the best) and monitoring (e.g., thinking about steps that can be taken to lower anxiety about writing the assignment). Irrespective of whether the strategies are observable or not, researchers have noted that learners' self-regulated learning process or use of meta-strategies is closely associated with motivation (Schunk and Zimmerman 2008; Schmitz and Wiese 2006)) as 'high motivation leads to significant use of language learning strategies ...high strategy use probably leads to high motivation as well' (Oxford and Nyikos 1989, 295; also see Yang 1999). Researchers have also found that learners' strategic selfregulation can enhance writing performance (Graham and Harris 2000). Consequently, research has been undertaken to explore these relevant processes. For example, Negretti's (2012) longitudinal study of student writers' self-regulated writing processes shifting over a semester finds that students assume more control over the writing process over time. Pifarré and Fisher (2011) conclude that technology facilitates better understanding of the writing processes and suggest that it is necessary to pay more attention to specific strategic processes or use of particular meta-strategies involved in self-regulated writing. In addition, research has compared self-regulated writing processes of skilled and less skilled writers. For example, Manchón and de Larios (2007) show that skilled writers tend to be inclined to devote 'more time to constructing their pragmatic, textual and ideational representations before putting pen to paper' when compared to less skilled writers (p. 579).

No consensus, however, has been reached on whether differences exist between skilled and less skilled writers in terms of self-regulated strategic writing. Cameron, Hunt and Linton (1996) found that young children also show high levels of self-regulation ability when writing under favourable conditions, suggesting that less skilled writers probably differ little from skilled writers in self-regulated writing. Most of the research on self-regulated writing has focused on 
meta-strategies and processes such as planning, monitoring and evaluating. However, as it is argued, the emphasis in these processes is too narrow to understand writing practices (Prior 2006), as ‘an individual’s mental processes cannot be comprehensively understood by separating them from or ignoring the discourse community in which the writer is situated' (Kang and Pyun 2013, 53). For this reason, researchers have used sociocultural perspectives on language learning to understand writing practices within learners' social, cultural and historical surroundings (Kang and Pyun 2013; Lantolf and Thorne 2006; Prior 2006).

\section{Self-regulated strategic writing from sociocultural perspectives}

Sociocultural perspectives on language learning help researchers understand how learners' strategic writing efforts are mediated by the environment and/or the context. The role of contextual resources in mediating mental development gets highlighted as the connections between incoming stimulation and human responses are realized through various links or mediators in the process (Luria 1976). The links or mediators can be artefact resources including

tools (e.g., dictionaries and textbooks) and signs (e.g., languages and symbols), community resources (a social group that undertakes the same actions with the same goals), rules (e.g., time and academic requirements), and division of labour (e.g., roles played and power relationship in the community) (Engeström 2001; Yu and Lee 2016). Wenden (1998) acknowledges the importance of contextual mediation on individual learners' learning process but she also contends that sociocultural research tends to overlook 'the knowledge/beliefs embedded in the setting or which emerge through the interaction that takes place in it' as 'a source of insight on learners'... operations' (p. 530). Therefore, it is important to explore how language learners use mediators 'to intentionally regulate their minds from both the outside world of objects and situations and the inside mental world' (Lei 2008, 219). 
In light of such theoretical considerations, writing researchers have explored how L2 learners use these mediating resources strategically for self-regulated writing (e.g., Lei, 2016; Yu and Lee, 2016). For example, Lei (2016) identified three strategies used by skilled student writers during the process of utilizing resources, namely, noticing, imitating and goal setting. The skilled student writers not only noticed and imitated the language used by professional writers and good student writers but also set goals to reinforce appropriation of the linguistic resources for writing. In contrast, less skilled student writers seldom noticed meaningful usage of language by others and could notice only superficial things in other writers' writings. Even when they noticed some good language used by professional writers and good student writers, they did not know how to imitate that in the writing process. Although less skilled student writers also set goals, these goals were often irrelevant to self-regulated writing. This study also calls for further attention to language learners' strategic utilization of resources in self-regulated writing. For this reason, the study adopted a multiple case study approach (Yin 2013) to address the following research question:

How do high achievers and underachievers strategically use resources in selfregulated writing for academic studies in the medium of English?

\section{The Study}

We conducted the study in Hong Kong, where secondary schools are allowed to choose English or Chinese (either Cantonese or Mandarin) as the medium of instruction for one or more content subjects. Dual goals were set for the EMI subject learning: learning of English and learning of subject contents (HKCDC 1998). In the school covered in the study, subjects such as Mathematics, Integrated Science (S1-2), Physics (S3), Chemistry (S3) and Biology (S3) are 
taught in the medium of English. To address the research question, we focused on students' writing process in the subject of Integrated Science (IS) since science-related subjects are taught or assessed through English by most secondary schools in Hong Kong ("SSP Profiles 2016/2017” 2016) as well as other countries (Dearden 2014). Although secondary students learn science-related topics as a part of General Studies in primary schools, they experience many challenges during the transition period because General Studies is usually taught in participants' mother tongue (Chinese). In the IS lessons, students are required to write sentences or short paragraphs in English when describing and explaining scientific concepts or phenomena (e.g., characteristics of vertebrates and invertebrates). The study examined students' self-regulated strategic writing in these circumstances.

\section{Participants}

Three high achievers and three underachievers in English and IS were identified with help from teachers who taught the Secondary 1 (Grade 7) IS class in the school. The selection of the students for participation was based on the latest examination results. The three high achievers were among the top 10 in Grade 7 and the three underachievers were among the bottom 10. A consent form was given to the participants and their parents, explaining the goal of the research and their commitment to the study. They well understood that the data they provided would be kept strictly confidential and would be used for research purpose only, and that participation or non-participation in the study would not affect participants' academic studies at all. All the six students and their parents gave their consent. Profile of the participants is presented in Table 1.

Table 1. Profile of participants 


\section{Data collection and analysis}

We collected data with regard to how the participants used resources strategically for selfregulated writing in English through lesson observation, stimulated recall and semi-structured interviews. First, we observed the participants' behaviours in four science lessons at the beginning of the academic year; field notes on students' behaviours of acquiring and using resources were taken. After the lesson observation, we collected student workbooks and the notebooks in which students themselves took notes for learning. We photographed their completed assignments in the workbooks (9-17 pages each student) and the notes taken (8-15 pages each student) for analysis. We also interviewed each student participant in the first language about the learning-to-write experience. The interview questions included 'how do you like the primary school you are from and the secondary school you are in', 'what do you usually do for the learning of IS in and out of classes', 'do you feel it is difficult to learn IS and to do IS assignment in English and why', 'what do you normally do when you have difficulties in doing IS assignment', and 'how do the teachers, your classmates, and your family members support you when you have difficulties in doing IS assignment'. Stimulated recalls were conducted after the interviews while the collected artefacts such as assignments and learning notebooks were used as the stimuli. In the stimulated recall, students were asked in the first language to recall what difficulties they had faced and how they responded to these in the writing process. In both interviews and stimulated recalls, students were asked to come up with their own descriptions of their strategies first. We then asked whether they had used the strategies they did not mention and why. Both semi-structured interviews and stimulated recalls were audio-taped and transcribed verbatim in Chinese by a research assistant. All transcripts were double checked by another person and were then analysed. The transcribed interviews and stimulated recalls, 
together with the field notes taken while observing the lessons, notes and written assignments were analysed in triangulation to support any claims that we have made in this paper.

The data were read deductively to identify the self-regulated process of resource usage. Participants' behaviours in terms of strategic resource utilization were coded into basic-level concepts, such as 'tagging certain pages in the textbook', 'drawing pictures to memorize new words', 'revising the mistakes before using the notes', 'noticing important information when teachers change their tones', 'copying especially important notes to another notebook', 'using exact words/phrases used in the textbook', and 'translating the sentences into Chinese for a better understanding'. Then similar basic-level concepts were aggregated into categories. For instance, the concepts 'drawing picture to memorize new words', 'memorizing new words in the textbooks,' and 'memorizing and understanding scientific facts and language through discussion with family members' were grouped into the analytic category, 'memorizing'. Different categories were compared constantly, across data sources and cases. The identified categories were revised based on the comparison before they were finalized (Corbin and Strauss 2014). To calculate interrater reliability for the current study, one of the authors and a trained research assistant coded the data of one participant independently. The inter-rater agreement was found to be $80 \%$, deemed acceptable. Discrepancies in coding were solved through discussions and the research assistant coded the rest of the data.

Finalized categories of self-regulated strategic processes included noticing, selecting, reorganizing, evaluating, reviewing and memorizing, imitating as well as adapting. Noticing refers to both the process and the result of knowing the fact that something has happened, as well as its features (Mason 2002). When noticing occurs, the learners know that important and/or useful resources are being provided. Selecting is a core function in self-regulated strategic 
learning. As mentioned previously, it is not the quantity and/or frequency of strategy use but the careful selection of appropriate strategies for a specific learning context that contributes to learning success. Similarly, when provided with various resources, learners need to choose the appropriate resources for learning. Reorganizing here means changing the way the learning materials were originally presented. Examples of reorganizing include relocating the resources, highlighting parts of the resources, and using symbols and colours to change the presentation of the resources. According to Novak (1977), meaningful learning occurs when learners modify their prior knowledge to accommodate the new knowledge, and reorganization of learning materials plays an essential role during this process. When learners come to the stage of evaluation, they check whether the language or the contents provided make sense to them. Reviewing and memorizing here refers to learners' attempts of remembering the language and/or contents provided in/by the resources. While imitating, learners copy the language and/or contents provided in/by the resources. During the process of adapting, learners modify the language and/or contents provided to suit the writing.

\section{Findings}

Results emerging from the analysis show that the high achievers and the underachievers use meta-strategies differently when using resources in the processes of self-regulated writing (Lei 2016). Instead of elaborating the relationships among these meta-strategies and strategic processes, the following sections focus on identification of the differences between the high achievers and the underachievers. However, it should be noted that the sequence in which the meta-strategies and strategic processes are presented does not indicate the sequence in which the meta-strategies and strategic processes happened. In reality, they did not happen in a linear 
sequence but were interlinked with each other. For example, evaluating the understanding of a resource can occur either/both before or after selecting the resource. When it occurred before selecting, the selection of the resources was based on the evaluation results, that is, resources that do not make sense to the learners are not selected for writing. This can also occur after selection. In this case, learners select the important or useful resources when they notice them first, and then check if the selected resources make sense. Further selection might be conducted if the evaluation results are negative. Such reiteration also applies to the rest of the meta-strategies during the self-regulated writing.

\section{Noticing}

Previous studies have showed that skilled learners notice a wide range of good writers' language usage and use that as a good resource to support their writing, but less skilled learners do not (Lei 2016). Data collected in this study also indicate that high achievers can determine the importance of a particular resource for retention. For instance, the high achievers could tell the importance of particular information for retention when they became aware of the changes in the teachers' presentation. Joey knew that the teachers were providing something that she might need to use for writing later when she heard the teacher repeating:

I know I need to write down 'close, otherwise the gas will leak out and it will be very dangerous', because this is what our teacher repeated several times. When he repeated it, I just wrote it down on my notebook. (Joey, interview).

In contrast, the underachievers failed to notice the important resources (Lei 2016). They had problems identifying important information to take notes on even when teachers signalled them to do so implicitly by changing voice tones and repetition. In the observed lessons, Frankie 
took notes only when the teacher explicitly asked the students to do so. He confessed in the stimulated recall interview that he did not know what notes to take if the teacher did not tell them. He would miss even the keywords used in the textbook that he could use for his own writing:

I checked the textbook to see if the words were used. But sometimes I just did it too fast to notice them. The next day when I went back to school and asked my classmates, and then I realized I just missed them when I checked the textbook. (Frankie, interview)

The high achievers not only noticed good language used in the provided resources but also bad ones. They noticed the wrong spellings in learning resources provided by teachers and knew they could not use them for their own writing. Katty was quite careful about using these notes for writing:

Some students spelled the words wrongly in their writing, just because the words were already wrong when they were written down in the notes. Mr. Tam said his handwriting was ugly, so we might not recognize the letters. So we may not recognize his handwriting. (Katty, interview)

The underachievers did not notice the mistakes in the same learning resources. For example, in a note excerpt that describes the features of fish, Cindy put down 'eling scales', which was supposed to be 'slimy scales'. Later when she tried to describe the features of fish in the assignment, she still put down 'eling', suggesting that she had not noticed the wrong spelling of the term.

In addition, the underachievers did not notice the different requirements the teachers set for science assignments in comparison with those in primary schools. They tended to write in the way they used to write when taking general studies in the first language in primary schools. In 
the school, Secondary 1 students are often required to write classification reports, naming things under different categories, while in primary schools, students are only required to name the categories. The underachievers were not aware of this difference in task requirements. As shown in the example of written assignment (Figure 1), students were expected to fill in one blank with 'dolphin, chimpanzee and salamander' and the other blank with 'earthworm and mantis'. However, the underachievers including Cindy and Thomas put down vertebrate and invertebrate in the two blanks and Frankie put down mammal and amphibian, names of the categories instead of animals under the categories.

Figure 1. Sample written assignment

In the stimulated call, Cindy explained, In primary school, part [of the report] was provided in Chinese, saying 動物主要分成兩要 組, 包括什麼什麼 (the animals can be categorized into two main groups, including...). I thought they were the same. My teacher told me that I should write down the details in future. That's when I knew I should write down the names of the animals. (Cindy, stimulated recall)

The above data excerpt indicates that Cindy did not notice the change in the task requirement when the different language was used. Even after she was told by the teacher that she needed to write differently for secondary school study, she did not know the new requirement was explicitly conveyed through the language used in the task instruction due to her low English proficiency. The same happened in the observed lessons when the teachers changed the requirements of writing experiment reports on the workbook. None of the underachievers noticed the differences while the high achievers did. 


\section{Selecting}

The participants were provided with quite a few resources (e.g., notes, textbooks and dictionary) to support learning of subject content and completing written assignments. For instance, they could use notes taken during lessons as an important resource when answering scientific questions in English. Yet our observations and interviews confirmed that not all students were able to copy all notes, whether orally given or written on the board by the teachers. Therefore, selecting information input from the teachers for note-taking and retention is a highly important strategy for the participants to acquire appropriate resources for completing written science assignments. The data revealed that the high achievers had a set of criteria to guide the selection of relevant inputs and always managed to select the useful among the resources provided for retention. For example, they took notes that did not appear in previous lessons or other learning materials and on things that were new, yet to be understood, or important to them. For example, Daniel reported,

I only take notes on the main points. I won't take all of them...for example, when he (the teacher) says something, a sentence, I understand some words. I will not write down the words that I know, but just write down those that are new to me. (Daniel, interview)

In contrast, the underachievers tended to either take whatever was provided or give up recording all the new resources provided. It seems they were overwhelmed by the mass of notes and felt intimidated when deciding what to record (Mason 2002). They could not identify what was important or what they had already received and for this reason, they tried to document whatever was provided to them. For instance, Cindy tried to note down every single word and image provided by the teacher and understand them after classes. Due to her low English 
proficiency, she could note down only some fragments of the lessons and tried to make up the rest by asking the teacher or classmates after class:

For the parts that I don't understand, I will ask my classmates after class, because their English is better than mine. I will ask my classmates, for the notes that I don't have. (Cindy, interview)

Sometimes, she spent too much time taking notes that were not important, because of the lack of ability to differentiate important information, as she recalled in the following extract:

I drew this [a typical plant cell] very slowly, because the line [of the cell wall] should be very straight and there are so many dots [referring to cytoplasm] in it. The teacher talked really fast but I was still drawing [the diagram]. (Cindy, stimulated recall)

The above extract suggests that Cindy did not know the straightness of the cell wall and the number of cytoplasm were not important for note-taking, and thus she spent much time drawing them. Lack of knowledge of which information was important or how to use the resources effectively also led the underachievers to give up using them. For example, Frankie did not take notes on any steps of the experiments provided by the teacher, which was the core knowledge in the lesson. He explained later,

I didn't take notes on the steps because I didn't think they were important. I took notes on experiment steps before, but they turned out to be useless. (Frankie, Stimulated recall)

Like Frankie, Cindy often gave up on taking notes of new resources because she understandably had difficulties in retaining all resources and did not know how to use them effectively for learning and writing. However, when provided clear instructions on what was important, she also selected the important resources as the high achievers did. For example, 
when writing a descriptive report of features of the bats, Cindy only referred to the highlighted parts in the textbook, as the teacher had told the students that only the highlighted parts were useful for the assignments.

The data also suggest that the underachievers knew they could skip what had been included in the learning materials when taking notes. However, they lacked knowledge about what resources were included in the existing learning materials and that led them to noting down whatever was provided. For example, Thomas said he had to scan the existing learning materials before he knew whether a particular note had been provided before. He therefore scanned related pages of the textbook that the teacher was teaching and then wrote down teacher's notes if they could not be found on those pages:

I will take notes only on what is not in the textbook or the unit handbook... when the teacher is teaching [contents in] some pages of the textbook, I will see whether the notes he gives us are included in those pages. If not, I will write down the notes. (Thomas, interview)

When they did not know how to use the provided resources, the underachievers gave up on using them. For instance, Frankie did not use the dictionary when he encountered difficult words during writing because he 'did not know how to use the Chinese words to look up the English words in the dictionary' (stimulated recall).

\section{Reorganizing}

Reorganization of learning materials plays an essential role during meaningful learning (Novak 1977). In this study, high achievers were found to have strategically reorganized the resources. They linked different but related resources by noting down the relevant referencing information or putting it together in the same note. For example, when taking notes on cells, Daniel added 
'irregular in shape' which was not in the notes provided by the teacher. According to him, this piece of knowledge was given in previous lessons. Similarly, when Joey noticed that Page 97 of the textbook and the notes provided were relevant to each other, she wrote down Page 97 next to the notes. However, the underachievers did not take such actions to reorganize the information they had received for reuse when writing.

The high achievers in the study did not always put everything together through reorganization. Instead of linking all the relevant information, they were found to have singled out some resources which they thought were extremely important for regular reviews. For example, Katty prepared a smaller notebook for herself where she put down notes important to her. She always brought the notebook with her so that she could review the notes anywhere anytime. The high achievers also changed the presentation of the notes to make them more systematic. The underachievers usually kept the resources the way they were when they were acquired. Figures 2 and 3 show how the high achievers and the underachievers reorganized the resources differently for future use.

Figure 2. Example notes taken by the underachievers

Figure 3. Example notes taken by the high achievers

Frankie copied notes provided by the teacher almost word-by-word. The only change he made was to change the colons into hyphens. This was the case with Cindy also, who only changed the colon into braces. In the stimulated recall interview, they explained that they had made the change to make the symbols understandable to themselves. In contrast, Daniel, the high achiever, reorganized the notes into a hierarchical diagram and added examples he found in the textbook to illustrate each category (e.g., frog, snake, whale and whale). Other high achievers such as Katty did the same thing. In the stimulated recall, all the three high achievers said they 
always organized learning resources by linking them together. Some information in Katty's notes (e.g., fin, gill, mammary gland) was missing, which indicates again that she was quite selective when reorganizing resources for use later.

In addition, we also found that the high achievers used colours and symbols (e.g., '*', ' $\square \square$ ', ‘ $\{$ ', ‘ $\sqrt{ }$ ') to highlight, differentiate, categorize and systematize the resources through lesson observations and interviews. However, the underachievers used much less of colours or symbols in notetaking and reorganization. Even when they used colours and symbols, they might not have done so to facilitate learning and future use of the acquired resources. For example, Thomas mentioned that the notes in a single colour were too boring and added that colours made the notes more interesting.

\section{Evaluating understanding}

As not all students actively evaluate whether the instruction makes sense to them (Baker and Brown 1984), the high achievers and the underachievers were found to have undertaken different strategic actions for evaluating their understanding of the learning resources before they

committed them to memory for future use. As reflected in the following, Katty always tried to find the meaning of relevant information and evaluated her understanding before retaining it as part of her resource repertoire:

I will ask them (the classmates) what the sentences mean. Sometimes they may not know [the correct one], but just give me a wrong answer. Usually I will see if what they say made sense. If not, I will ask my mom. (Katty, interview)

Apparently, Katty did not use the information if she did not understand it properly. She persisted in finding out what the information meant from her peers and significant others such as 
her mother until she understood it. Apart from such strategic efforts, the high achievers such as Katty and Daniel used their first language to evaluate their understanding. Katty translated assignments' writing requirements into Chinese when she did not understand them. She sometimes found the writing comparatively easier than the assignments' writing instructions since she had already memorized both the language and the contents for the written assignments. Her difficulties were normally caused by the difficult writing instructions. Daniel always memorized the notes in English since he was expected to write the assignments in English. Prior to memorization, he usually thought about the notes' meaning in Chinese to make sure that he had understood the notes:

I shall memorize. That is, I shall review the words. Before that I will see if I understand them...I need to memorize them in English because the assignments are required to be written in English. I will translate them into Chinese and see if they make sense. (Daniel, interview)

The study identified that the underachievers tended to use the resources even before understanding them properly. For instance, when asked to list the animals whose body temperature is not easily affected by the environment in a written assignment, Cindy wrote down 'Yes, I do. Fish, eling scales', which did not make any sense. In the stimulated recall, she explained why she did this:

I didn't understand [the requirements]. I asked my classmates but they didn't answer, so I thought they didn't understand either. Then I heard someone saying this. I repeated it and asked him. He nodded his head so I thought it was the correct answer, then I just put it down. (Cindy, stimulated recall) 
As can be seen in the above excerpt, Cindy did not try to understand the assignment's written instructions and answers provided by her peers properly. Nevertheless, she used them to answer the question.

\section{Reviewing and Memorizing}

Reviewing and memorizing are important strategic processes for effective self-regulated learning (Bouffard et al. 1995). In this study, the high achievers were found to have reviewed and memorized acquired information for retention and future use from time to time. They reviewed and memorized subject knowledge such as steps of experiments, features of animals, components of equipment, and definition of the phenomenon as well as English grammar, words and pronunciation. As a result, they did not have to constantly consult notes and textbooks when completing written assignments since they had already memorized the relevant information. They deployed different strategies to memorize the subject knowledge and the language. For instance, Daniel memorized them through doing exercises. He explained as follows:

For example, if you do a lot of exercises like this, you will know they are mammals, because they have hair. (Daniel, stimulated recall)

According to the above data, exercises helped him to get more and more familiar with the content and the language. Joey memorized difficult words according to the syllables. She said,

I like reading English books and I always memorize the pronunciation of new words. I don't have problem with these words, because they appeared in the books I read before. I can spell them according to the pronunciation. Take 'antelopes' for example, I will write down 'an', and then 'te', and then 'lopes'. (Joey, stimulated recall) 
The above data show that Joey always memorized pronunciation of words new to her when reading English books. As a result, she could easily spell words when writing. The fact that she liked reading English books also indicates Joey’s high English learning motivation. Besides, she also memorized difficult words through drawing pictures, which helped her to memorize the meaning of the words. Katty also reported having used similar strategies.

The underachievers did not review or memorize much of the difficult parts of language or subject knowledge. They often consulted notes or textbooks for help if they had difficulties in writing answers or they simply wrote down their 'impressions'. For example, Frankie recalled how he looked for sentences in the textbook or notes with particular words he had noticed in the assignment question so that he could copy them to answer it. It is likely that the underachievers were not particularly motivated to invest learning efforts. Participants like Frankie did not think review and memorization were necessary since he could finish the assignment without doing these. It seems he really wanted to finish the assignment but did not care whether he had the correct answers when completing written assignments:

I just wanted to finish this. That means, for example, when I didn't know what to write here, I just moved on to the next one. I just wrote down what was in my impression. (Frankie, stimulated recall)

Frankie's indifference to the correctness of his answers to the assignments showed that low motivation might be a reason for not reviewing or memorizing. The underachievers were also likely to be overwhelmed by difficult language and subject content. During one of the lessons, when Cindy was asked to write down the features of mammals, she simply went back to the textbook and found the sentences that she was asked by the teacher to memorize. Instead of memorizing them, she simply copied the sentences in her writing. In the subsequent stimulated 
recall interview, she confessed that she did not have time to memorize them because " $[\mathrm{t}] \mathrm{here}$ are too many things new to me...I almost spent every night reviewing and memorizing English words'. (Cindy, stimulated recall)

\section{Imitating}

Extant research confirms that skilled writers persistently imitate good writers' writing while less skilled writers hesitate to do so even when they notice the language used by good writers (Lei 2016). In this study, both the high achievers and underachievers were found to have imitated the writing in the textbook and other learning materials as they believe that scientific writing needs to be accurate and the aforementioned learning materials are considered accurate. Further analysis revealed that the two groups of participants imitated under different circumstances. All the high achievers did it when they were not sure about the written assignments. For instance, Joey recalled when she was completing a paragraph on the workbook to describe a whale, she imitated the language in the paragraph on the same page describing dinosaur and penguin, such as 'it is a vertebrate because...This can be further classified under the group of...because...'. Her final writing was:

Whale is not a fish because it has hair. A whale is a vertebrate because it has a mammary gland. It doesn't lay eggs. It is a vertebrate because it has a backbone. This can be further classified under the group of mammal, because it has hair. (Joey, stimulated recall)

She also explained that she imitated the words, sentences and structure of the previous paragraph because it is 'easier to imitate the examples' and 'doing that will guarantee correct writing' (Joey, stimulated recall). 
The underachievers, including Cindy and Thomas, imitated the language in the examples as Joey did. Cindy used 'it is a vertebrate because' while Thomas used 'It can be further classified under the group of'. However, unlike Joey, they could not synthesize the example sentences in different places; they only imitated those that could be easily noticed and located. As indicated above, they both imitated examples from the same page where they wrote, which could be easily noticed. Cindy imitated the writing in the notes because their importance had been greatly emphasized by the teacher. Frankie also imitated the writing in the learning materials, but he did not do so most of the time as reflected in the written assignments. Instead, he tended to write down only those that he remembered, according to his interview responses. This may again be due to lack of learning motivation, reflected in his interview responses, such as 'I only care about finishing the assignment', 'I will just leave it like this [no matter whether it is correct]'.

\section{Adapting}

As noted by Tomlinson (2012), good teachers always adapt learning materials. This applies to good learners also. When completing written assignments, the high achievers did not use the acquired resources right away and usually adapted them for use. For instance, they summarized subject knowledge instead of directly copying it when taking notes. They also adapted the language, especially when they detected errors. As mentioned earlier, Katty always revised the writing if she saw wrong spellings in the notes and adapted her writing according to specific requirements. In addition, they also adapted scientific facts to specific contexts provided in the questions. For instance, an exercise in the workbook required learners to state two errors in the diagram of a typical plant cell drawn by Nancy, where words like 'vacuole' and 'nucleus' were 
tagged to indicate parts of the cell. A similar diagram with words and phrases was shown in the textbook. Both the high achievers and the underachievers knew that the textbook could be used to answer the question but they used it in different ways. Katty and Joey knew that they could not copy the words directly but instead they adapted these words and phrases as follows:

She missed the cell wall and cytoplasm (Katty, Workbook, p. 61)

The vacuole isn’t big enough \& there are no cytoplasm (Joey, Workbook, p. 61)

By contrast, Thomas simply copied 'cell wall' and 'cell membrane' while he was supposed to write ‘There was no cell wall and she did not label cell membrane.' In the interview, he explained that he did not know that he was supposed to write a complete sentence. Thomas was not aware that the errors could not have been pointed out adequately without complete sentences. Unlike Thomas, Frankie knew that he needed to change the words or phrases into a sentence, but he did not know the meaning of the sentence. He wrote:

“.. only plant cells have... a wall and a large vacuole” (Frankie, Workbook, p. 61)

When writing, he put down 'a wall' instead of 'cell wall' which was in the diagram in the textbook. This indicates he had not referred to the textbook. However, the fact that he spelled the technical term 'vacuole' correctly, which was in the diagram as a part of the exercise, indicated again that he only imitated the resources that were easily noticed and located, and when they were not, he just wrote whatever he could remember. This suggests that the underachievers often did not adapt the resources for writing because they failed to decide whether it was necessary for them to adapt. Frankie's case also explains why the underachievers could not imitate good writing in the process. The underachievers tended to directly use the language without adaptation 
because they were unable to decide whether a particular use was accurate or proper. In such circumstances, the underachievers like Cindy even wrote down sentences copied from peers even though they did not make sense (see example of Cindy's stimulated recall in the section 'Evaluating understanding').

\section{Discussion}

Drawing on sociocultural perspectives (Lantolf 2006), the study explored learners' self-regulated strategic writing for academic studies in an EMI context as a phenomenon emerging from interaction between individual learners and contextual conditions. As reminded by Wenden (1998), the study focused on how the students acquired and used sociocultural resources strategically to mediate their self-regulated writing for academic studies. The study expanded from the processes of noticing and imitating highlighted in previous research by identifying and examining five more meta-strategies or strategic processes of using resources, including selecting, reorganizing, evaluating understanding, reviewing and memorizing and adapting. These identified meta-strategies and strategic processes reflect a more complete picture of the mediation of sociocultural resources on learners and their use of these resources strategically for self-regulated writing.

Echoing the results from previous research (e.g., Manchón and de Larios 2007), the study confirms that high achievers and underachievers differ in terms of self-regulated strategic writing. The high achievers' self-regulated strategic writing involves all the seven processes, revealing how these learners appropriate sociocultural resources strategically (Lantolf 2006; Manchón and de Larios 2007). They select useful resources based on a set of criteria. They also notice language resources that they can use for academic writing (Lei 2016) as well as the errors that should be avoided or adapted. Besides, they use various strategies to reorganize resources, 
including linking relevant pieces of resources to each other, separating the most important ones from others, changing the presentation of notes with colours and symbols. Also, they were found to always evaluate the quality of the provided resources, review and memorize those that made sense and were of good quality, imitate the language (ibid) when they were not sure about it, and adapte them when errors were detected and when they did not fit the specific writing requirements. In contrast, the underachievers' self-regulated strategic writing only involves imitating and limited reorganizing. They do not select useful resources from the inputs provided by their peers and teachers but tend to either acquire whatever is provided or give up new resources if they cannot manage. They seldom notice important and useful resources even when provided to them. They usually cannot tell whether there are mistakes in the resources, or whether writing requirements are different from those of other tasks. In addition, they tend to use the resources before understanding, memorizing or adapting them. Even when the writing involves imitating like high achievers, they find it difficult to locate useful language to imitate. They only imitate what can be easily noticed and located. Sometimes they were found to have given up imitating altogether as they were not particularly motivated to sustain the imitation.

Findings of this study indicate that the underachievers have limited knowledge of metastrategies and strategic processes for self-regulated writing, which explains why they did not use these meta-strategies and processes (e.g. Wenden 1998). For example, some of them might not know the resources provided were different in terms of importance and quality. Nor did they know the resources could be reorganized to facilitate memorization. In addition, they might not know the resources should sometimes be adapted before being used for writing. The results also confirm that inadequate L2 proficiency among learners causes problems for learning in L2medium contexts (Tam 2011; Evans and Morrison 2011). They further show that different 
degrees of L2 proficiency can also explain the differences between the high achievers and the underachievers in terms of resource utilization processes of self-regulated strategic writing for academic studies in such contexts. Due to inadequate English proficiency, the underachievers had difficulties in taking notes in the class, noticing good language resources, making sense of most of the resources provided, memorizing new resources provided to them, and adapting the resources before using them. Previous research has suggested that motivation highly likely affects self-regulated strategy usage (Oxford and Nyikos 1989; Pintrich and de Groot 1990; Yang 1999). This study also found that underachievers like Frankie did not memorize or just copied sentences which he thought might be suitable for his writing without understanding, which is indicative of absence of investment and low learning motivation.

To address these identified issues in the participants' self-regulated writing, we argue that self-regulated strategy instruction can have the desired effects when dealing with written assignments in subject learning (Graham and Perin 2007). Teaching underachievers the selfregulated processes used by high achievers may be a possible way to deal with their difficulties in such a context. Although we are fully aware that teaching does not necessarily translate into students' learning gains, explicit instruction of the processes and scaffolding during the process can help to raise learners' awareness, improve their strategic knowledge and encourage them to use the processes (Wenden 1998; Moos and Azevedo 2008; Azevedo et al. 2008), especially for those who lack strategic knowledge of self-regulated writing processes. If underachievers are also given opportunities to practice strategies for self-regulated learning, they may be empowered with a better sense of self-efficacy and become motivated to invest more efforts in the learning process (Schmitz and Wiese 2006; Stoeger and Ziegler 2008)). 
Since the effectiveness of explicit strategy instruction may be undermined by factors such as learners' commitment to developing new strategies, their readiness to use these strategies and teachability of particular strategies (e.g. Griffiths 2013; Oxford 2011), we suggest that teachers should not simply ask underachievers to do whatever high achievers do; tailor made support for individual students should be designed and developed. Based on the findings of this study, one possible example of such support is asking students questions from time to time and helping them to form a habit of generating questions during self-regulated learning for writing, which is viewed as an important self-regulatory strategy (Rosenshine, Meister, and Chapman 1996). To raise students' awareness of differences between resources in terms of importance, teachers can ask students to reflect on questions such as 'what resources are important', 'in what way they are important', and 'how do you know they are important' when the resources are provided. To further enhance students' ability to select resources, teachers can ask the questions 'how is one resource different from another', 'which previously provided resources are relevant to the newly provided ones', 'do you find the language and contents in the provided resources clear and correct', 'did we learn this before', 'when did we mention this', and 'do you think you should take notes on this piece of information and why'. To raise students' awareness of the need for reorganizing, teachers can ask 'how can we make the notes more systematic' and 'what we should do with the relevant resources'. To help students to form a habit of evaluating understanding, teachers can invite them to reflect on questions such as 'what does this mean in Chinese' and 'does this answer make sense to you'. In the beginning of every class, teachers may also check whether the students, especially underachievers, have reviewed and memorized what they learnt in previous lesson. To enhance students' ability to imitate and adapt, teachers can ask 'what are the words, sentences used in the textbook to describe this', and 'do you think it proper 
to copy the sentence used in the textbook for the writing of the exercise'. In addition, teachers may also demonstrate how a particular meta-strategy or strategic process can be used to regulate writing.

For those with low L2 proficiency, we suggest teachers encourage them to use more L1 to facilitate understanding of the subject contents (Lo 2015). Using English as the medium of instruction not only impedes low-L2-proficient learners' understanding of subject contents (Lo and Lo 2014), but it also hinders the use of self-regulated learning processes. Therefore, we suggest schools reconsider the pros and cons of policies of instruction medium, schedule the classes based on learners’ L2 proficiency, and consider using learners' L1 to teach students with low L2 proficiency (Lo 2015). As we believe that motivation is both a source and an outcome of students’ strategic self-regulated writing efforts (Schmitz and Wiese 2006; Stoeger and Ziegler 2008), explicit strategy instruction will help students with low learning motivation. These students will be more motivated to self-regulate the writing process strategically if they are taught explicitly how to self-regulate and given opportunities to do so. As they are encouraged to regulate the strategic writing process and become much more aware of learning progress, they are also motivated to sustain their strategic learning efforts for self-regulated writing. We would also like to reminder teachers that students' strategy expertise and L2 competence are only built up over time. Therefore, explicit strategy instruction cannot be a short-term measure to support their self-regulated strategic writing. Instead, explicit strategy instruction needs to be incorporated as an integral part of regular, ongoing teaching that is designed to not only improve students' linguistic competence and subject knowledge but also enhance their capacity for selfregulated strategic writing. 


\section{Conclusion}

This study compared self-regulated strategic writing for academic studies in an EMI context. The high achievers were found to have adopted different strategic processes compared with underachievers because they had different perceptions and knowledge of self-regulated writing processes, L2 proficiency and learning motivation. In light of such findings, we conclude that teachers should continuously provide underachievers explicit instructions and scaffolding to facilitate self-regulated writing for academic learning. Given that learners’ L2 proficiency cannot be improved in a short period of time, we suggest that schools consider adjusting their policies of instruction medium. We also suggest teachers be aware of individual differences in terms of learning motivation and focus on enhancing motivation. Further research is needed to explore how teachers can motivate students to self-regulate their writing.

Although findings of this small-scale study cannot be generalized to a larger population, they do contribute to the understanding of self-regulated strategic writing. Highlighting the distinguishable features of self-regulated writing for completing written assignments, the study reveals the difficulties that underachievers encounter in self-regulated writing. We believe that such findings constitute pedagogical resources for teachers to increase students' awareness of their self-regulated writing processes, and for researchers and educators to further develop pedagogy for the enhancement of self-regulated writing.

\section{References}

Azevedo, Roger, Daniel C. Moos, Jeffrey A. Greene, Fielding I. Winters, and Jennifer G. Cromley. 2008. "Why Is Externally-Facilitated Regulated Learning More Effective than Self-Regulated Learning with Hypermedia?” Educational Technology Research and Development 56 (1): 45-72. doi:DOI 10.1007/s 11423-007-9067-0.

Bai, Barry. 2015. “The Effects of Strategy-Based Writing Instruction in Singapore Primary Schools.” System 53. Elsevier Ltd: 96-106. doi:10.1016/j.system.2015.05.009.

Baker, Linda, and Ann L. Brown. 1984. “Metacognitive Skills and Reading.” Handbook of Reading Research 1: 
353-394. http://files.eric.ed.gov/fulltext/ED195932.pdf.

Bouffard, Thérèse, Jacques Boisvert, Carole Vezeau, and Claudette Larouche. 1995. "The Impact of Goal Orientation on Self-Regulation and Performance among College Students.” British Journal of Educational Psychology 65: 317-29. doi:10.1111/j.2044-8279.1995.tb01152.x.

Cameron, Catherine A., Anne K. Hunt, and Murray J. Linton. 1996. "Written Expression as Recontextualization: Children Write in Social Time.” Educational Psychology Review 8 (2): 125-50.

Campbell, Jacqui, and Mingsheng Li. 2007. “Asian Students' Voices: An Empirical Study of Asian Students' Learning Experiences at a New Zealand University.” Journal of Studies in International Education 12 (4): 375-96. doi:10.1177/1028315307299422.

Corbin, Juliet, and Anselm Strauss. 2014. Basics of Qualitative Research: Techniques and Procedures for Developing Grounded Theory. 4th ed. SAGE Publications.

Dearden, Julie. 2014. "English as a Medium of Instruction -- A Growing Global Phenomenon." http://doi.org/10.1080/0013191610140107.

Engeström, Yrjö. 2001. "Expansive Learning at Work: Toward an Activity Theoretical Reconceptualization.” Journal of Education and Work 14 (1): 133-56. doi:10.1080/13639080020028747.

Evans, Stephen, and Bruce Morrison. 2011. "The Student Experience of English-Medium Higher Education in Hong Kong.” Language and Education 25 (2): 147-62. doi:10.1080/09500782.2011.553287.

Ghavamnia, Maedeh, Saeed Ketabi, and Mansoor Tavakoli. 2013. "L2 Reading Strategies Used by Iranian EFL Learners: A Think-Aloud Study.” Reading Psychology 34 (4): 355-78. doi:10.1080/02702711.2011.640097.

Graham, Steve, and Karen R. Harris. 2000. "The Role of Self-Regulation and Transcription Skills in Writing and Writing Development.” Educational Psychologist 35: 3-12.

Graham, Steve, and Dolores Perin. 2007. "A Meta-Analysis of Writing Instruction for Adolescent Students.” Journal of Educational Psychology 99 (3): 445-76. doi:10.1037/0022-0663.99.3.445.

Griffiths, Carol. 2013. The Strategy Factor in Successful Language Learning. Bristol: Multilingual Matters.

—. 2015. "What Have We Learnt from ' Good Language Learners '?” ELT Journal 69 (4): 425-33. doi:10.1093/elt/ccv040.

Hong Kong Curriculum Development Council (HKCDC). 1998. "Syllabus for Secondary Schools: Science (Secondary 1-3).” Hong Kong. http://www.edb.gov.hk/en/curriculum-development/kla/scienceedu/curriculum-documents.html.

Kanno, Yasuko, and Linda Harklau. 2012. Linguistic Minority Students Go to College: Preparation, Access, and Persistence. New York: Routledge.

Kang, Yon-Soo, and Danielle O. Pyun. 2013. "Mediation Strategies in L2 Writing Processes: A Case Study of Two Korean Language Learners.” Language, Culture and Curriculum 26 (1): 52-67. doi:10.1080/07908318.2012.762012.

Lantolf, James P. 2006. "Sociocultural Theory and L2: State of the Art: State of the Art." Studies in Second Language Acquisition 28 (1): 67-109. doi:10.1017/S0272263106060037. 
Lantolf, James P., and Steven L. Thorne. 2006. Sociocultural Theory and the Genesis of Second Language Development. Oxford: Oxford University Press.

Lei, Xiao. 2008. "Exploring a Sociocultural Approach to Writing Strategy Research: Mediated Actions in Writing Activities.” Journal of Second Language Writing 17 (4): 217-36. doi:10.1016/j.jslw.2008.04.001.

Lei, Xiao. 2016. "Understanding Writing Strategy Use from a Sociocultural Perspective : A Multiple-Case Study of Chinese EFL Learners of Different Writing Abilities.” System 60. Elsevier Ltd: 105-16. doi:10.5353/th_b4308567.

Lo, Yuen Y. 2015. “How Much L1 Is Too Much? Teachers’ Language Use in Response to Students’ Abilities and Classroom Interaction in Content and Language Integrated Learning." International Journal of Bilingual Education and Bilingualism 18 (3): 270-88. doi:10.1080/13670050.2014.988112.

Lo, Yuen Y., and Eric S. C. Lo. 2014. "A Meta-Analysis of the Effectiveness of English-Medium Education in Hong Kong.” Review of Educational Research 84 (1): 47-73. doi:10.3102/0034654313499615.

Luria, Aleksandr R. 1976. Cognitive Development: Its Cultural and Social Foundations. Cambridge, MA: Harvard University Press.

Manchón, Rosa M., and Julio R. de Larios. 2007. "On the Temporal Nature of Planning in L1 and L2 Composing." Language Learning 57 (4): 549-93. doi:10.1111/j.1467-9922.2007.00428.x.

Mason, John. 2002. Researching Your Own Practice: The Discipline of Noticing. London \& New York: Routledge.

Moos, Daniel C., and Roger Azevedo. 2008. "Monitoring, Planning, and Self-Efficacy during Learning with Hypermedia: The Impact of Conceptual Scaffolds.” Computers in Human Behavior 24 (4): 1686-1706. doi:10.1016/j.chb.2007.07.001.

Negretti, Raffaella. 2012. "Metacognition in Student Academic Writing: A Longitudinal Study of Metacognitive Awareness and Its Relation to Task Perception, Self-Regulation, and Evaluation of Performance.” Written Communication 29 (2): 142-79. doi:10.1177/0741088312438529.

Novak, Joseph D. 1977. A Theory of Education. Ithaca, NY: Cornell University Press.

Oxford, Rebecca L., and Martha Nyikos. 1989 "Variables affecting choice of language learning strategies by university students.” Modern Language Journal 73: 291-300. DOI: 10.1111/j.1540-4781.1989.tb06367.x

Oxford, Rebecca L. 2011. Teaching and Researching: Language Learning Strategies. London: Longman.

Pifarré, Manoli, and Ros Fisher. 2011. "Breaking up the Writing Process: How Wikis Can Support Understanding the Composition and Revision Strategies of Young Writers.” Language and Education 25 (5): 451-66. doi:10.1080/09500782.2011.585240.

Pintrich, Paul R., and Elisabeth V. de Groot. 1990. "Motivational and Self-Regulated Learning Components of Classroom Academic Performance.” Journal of Educational Psychology 82 (1): 33-40. doi:10.1037/00220663.82.1.33.

Prior, Paul. 2006. “A Sociocultural Theory of Writing.” In Handbook of Writing Research, edited by S. Graham C. A. MacArthur and J. Fitzgerald, 54-66. New York: The Guilford Press.

Rosenshine, Barak, Carla Meister, and Saul Chapman. 1996. "Teaching Students to Generate Questions : A Review of the Intervention Studies." Review of Educational Research 66 (2): 181-221. 
Schmitz, Bernhard, and Bettina S. Wiese. 2006. "New Perspectives for the Evaluation of Training Sessions in SelfRegulated Learning: Time-Series Analyses of Diary Data.” Contemporary Educational Psychology 31 (1): 64-96. doi:10.1016/j.cedpsych.2005.02.002.

Schunk, Dale H., and Barry J. Zimmerman. 2008. Motivation and Self-Regulated Learning: Theory, Research, and Applications. Mahwah, NJ: Lawrence Erlbaum.

“SSP Profiles 2016/2017.” 2016. Accessed December 9. http://www.chsc.hk/ssp2016/eng/index.php.

Stoeger, Heidrun, and Albert Ziegler. 2008. "Evaluation of a Classroom Based Training to Improve Self-Regulation in Time Management Tasks during Homework Activities with Fourth Graders.” Metacognition and Learning 3 (3): 207-30. doi:10.1007/s11409-008-9027-z.

Tam, Angela C. F. 2011. "Does the Switch of Medium of Instruction Facilitate the Language Learning of Students? A Case Study of Hong Kong from Teachers’ Perspective.” Language and Education 25 (5): 399-417. doi:10.1080/09500782.2011.573076.

Tomlinson, Brian. 2012. "Materials Development for Language Learning and Teaching.” Language Teaching 45 (452): 143-79. doi:10.1017/S0261444811000528.

Vann, Roberta J., and Roberta G. Abraham. 1990. "Strategies of Unsuccessful Language Learners.” TESOL Quarterly 24 (2): 177-98. doi:10.2307/3586898.

Wenden, Anita. 1998. "Metacognitive knowledge and language learning.” Applied Linguistics 19(4): 517-537. doi:10.1093/applin/19.4.515.

Wong, Albert T. Y. 2005. "Writers' Mental Representations of the Intended Audience and of the Rhetorical Purpose for Writing and the Strategies That They Employed When They Composed.” System 33 (1): 29-47. doi:10.1016/j.system.2004.06.009.

Yang, Nae-Dong. 1999. "The relationship between EFL learners' beliefs and learning strategy use.” System 27 (4):515-535. doi: 10.1016/S0346-251X(99)00048-2

Yin, Robert K. 2013. Case Study Research: Design and Methods. Log Angeles: Sage.

Yu, Shulin, and Icy Lee. 2016. “Exploring Chinese Students' Strategy Use in a Cooperative Peer Feedback Writing Group.” System 58. Elsevier Ltd: 1-11. doi:10.1016/j.system.2016.02.005.

Table 1. Profile of participants

\begin{tabular}{|l|l|l|}
\hline Groups & Name (pseudonyms) & Gender \\
\hline High achievers & Katty & Female \\
& Joey & Female \\
& Daniel & Male \\
\hline
\end{tabular}




\begin{tabular}{|l|l|l|}
\hline Underachievers & Cindy & Female \\
& Frankie & Male \\
& Thomas & Male \\
\hline
\end{tabular}

Figure 1. Example written assignment

1. The photos below show some animals.

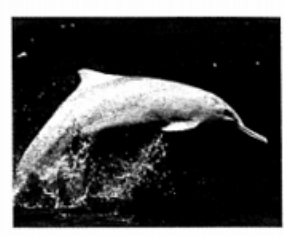

Dolphin

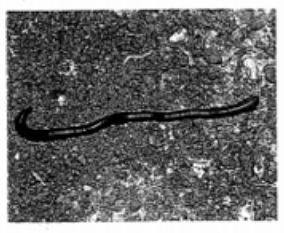

Earthworm

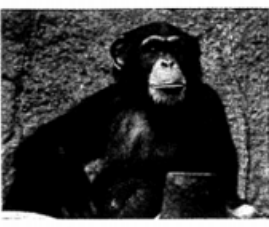

Chimpanzee
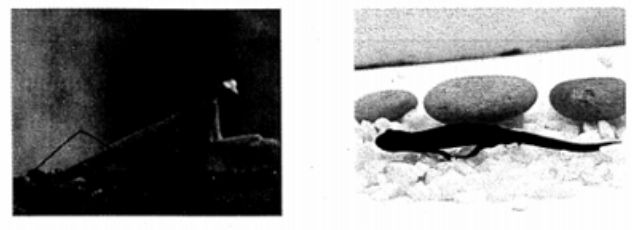

Salamander

(a) (i) Classify the above animals into two main groups.

One group includes vertebrate

The other group includes invertebrate

(Thomas, workbook, p. 37)

Figure 2. Example notes taken by the underachievers

Vertebrate

1. Fish -- slimy scale, fin, gill

2. Amphibian -- naked, moist skin

3. Reptiles -- dry scales

4. Bird -- feathers, beak, fing

5. Mammal --hair, mammary gland (Frankie, Handbook, p. 38)

Figure 3. Example notes taken by the high achievers 
Vertebrate (has back bone)

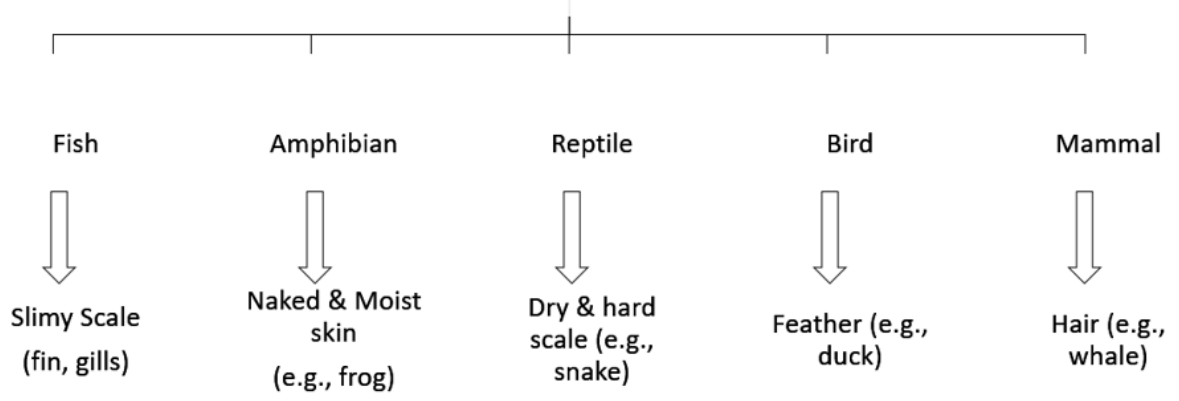

(Daniel, Handbook, p. 39) 